\title{
FORTY YEARS OF LABOUR LAW SCHOLARSHIP IN NEW ZEALAND: A REFLECTION ON THE CONTRIBUTION OF GORDON ANDERSON
}

\section{Richard Mitchell*}

This special issue of the Victoria University of Wellington Law Review is published in recognition of Gordon Anderson's outstanding contribution to the study of the academic and socioeconomic policy field of labour law in New Zealand since the mid-1970s. During this period of time Gordon's work has informed both teaching and learning in labour law scholarship and legal practice, ${ }^{1}$ charted the shifts in labour law policy, ${ }^{2}$ and examined the implications of these shifts for industrial and employment relations and human resource practices in business. ${ }^{3}$ This impressive output has included the publication of several full-length accounts of New Zealand labour law, incorporating background history, economic and political contexts and institutional arrangements, accompanied by analytical accounts of the general principles of individual and collective regulation. ${ }^{4}$ At the same time his research work, and his extensive engagement with labour lawyers internationally, has considerably

* Department of Business Law and Taxation, Monash University. I thank Harry Glasbeek, Richard Hill, Barbara Shalit and Carolyn Sutherland for the benefit of their advice on earlier versions of this article.

1 See for example Gordon Anderson and others (eds) Mazengarb's Employment Law (online ed, LexisNexis).

2 See Gordon Anderson Reconstructing New Zealand's Labour Law: Consensus or Divergence? (Victoria University Press, Wellington, 2011).

3 See Gordon Anderson, Peter Brosnan and Pat Walsh "Flexibility, Casualisation and Externalisation in the New Zealand Workforce" (1994) 26 JIR 491. See generally Gordon Anderson and others (eds) Transforming Workplace Relations in New Zealand 1976-2016 (Victoria University Press, Wellington, 2017).

4 See for example Gordon Anderson and John Hughes Employment Law in New Zealand (LexisNexis, Wellington, 2014); Gordon Anderson Labour Law in New Zealand (2nd ed, Wolters Kluwer, Alphen aan den Rijn (Netherlands), 2015); and Gordon Anderson, John Hughes and Dawn Duncan Employment Law in New Zealand (2nd ed, LexisNexis, Wellington, 2017). 
expanded the international understanding and interest in New Zealand's labour law system, drawing it more immediately and closely into comparison with other national systems and sets of laws. ${ }^{5}$

Gordon began his academic career teaching commercial law in the business school at Massey University, Palmerston North, in 1973. It was at this point in time that he also began teaching labour law. ${ }^{6}$ In 1977 he moved to the Commercial Law Group in the Faculty of Commerce and Administration at the Victoria University of Wellington. There he taught (among other things) labour law to business students and while still in that Faculty he also began teaching labour law in the Faculty of Law. Gordon moved to the Faculty of Law at the Victoria University of Wellington in 2002, and became a Professor in that Faculty in $2007 .^{7}$

In addition to his teaching and research roles across these different universities and faculties, Gordon has made a constructive contribution in several other respects. In 1980 he became (with his colleagues Peter Brosnan, David Smith and Pat Walsh) part of the editorial group responsible for the New Zealand Journal of Industrial Relations. ${ }^{8}$ For several years he was associate editor, then joint editor, of that journal. He played a key role in the establishment of the New Zealand Institute of Industrial Relations Research in 1983. Gordon also played a lead role in the formation of the New Zealand Labour Law Society in 2009 (President 2009-2018), and has held senior administrative positions as Associate Dean (Research) and Director of Postgraduate Studies in the Faculty of Law. This is to mention just a few of Gordon's contributions at an institutional level.

As indicated, Gordon's scholarship has covered a very broad spectrum of subject matter across the general field of labour law and associated areas of study. ${ }^{9}$ Some of his earlier work included articles on strikes and industrial disputes, ${ }^{10} \mathrm{ILO}$ Standards, ${ }^{11}$ and with some of his industrial relations specialist colleagues, studies focussed on changing work and labour market practices. ${ }^{12}$ However, for

5 See for example Gordon Anderson, Douglas Brodie and Joellen Riley The Common Law Employment Relationship: A Comparative Study (Edward Elgar, Cheltenham (UK), 2017).

6 Anderson Reconstructing New Zealand's Labour Law, above n 2, at 9.

7 Gordon Anderson "Employment Rights in an Era of Individualised Employment" (2007) 38 VUWLR 417.

8 The journal was renamed The New Zealand Journal of Employment Relations in 2004.

9 It should be noted that Gordon's work also includes a valuable contribution in the area of international trade law, with which we are not concerned in this review.

10 See for example Gordon Anderson "The Disadvantages of Injunctions in Industrial Disputes" [1975] NZLJ 179; Gordon Anderson "The Reception of the Economic Torts into New Zealand Labour Law: A Preliminary Discussion" (1987) 12 NZJIR 89; Gordon Anderson "Strikes and the law: the problems of legal intervention in labour disputes" (1988) 13 NZJIR 21; and John Hughes and Gordon Anderson "Injunctions and compliance orders: an analysis of the Labour Court's powers and decisions" (1988) 13 NZJIR 49.

11 Gordon Anderson "International labour standards and the review of industrial law" (1986) 11 NZJIR 27.

12 See for example Gordon Anderson, Peter Brosnan and Pat Walsh "Homeworking in New Zealand: Results from a Workforce Survey" (1994) 2 IJES 229; Gordon Anderson, Peter Brosnan and Pat Walsh "Adapting to 
the purposes of this brief review a few themes are noted which are presented as some measure of his thinking about New Zealand labour law from both a national and international standpoint. ${ }^{13}$

\section{THE CONTRACT OF EMPLOYMENT AND THE INDIVIDUAL EMPLOYMENT RELATIONSHIP}

The role of law in regulating the individual work relationship between employer and employee/worker has been a feature of Gordon's scholarship over the entire period of his career. In the early years this work included a focus on the statutory protection offered to workers in relation to dismissals, ${ }^{14}$ but clearly the introduction of the Employment Contracts Act in 1991, and its subsequent replacement by the Employment Relations Act of 2000, provided ample opportunity for continued focus on the role of the individual employment relation in the regulation of industrial relations in New Zealand. Most recently this has been expanded and elaborated upon in his work on the common law employment relation across several countries. ${ }^{15}$ The individual dimension of employment regulation was the topic of Gordon's inaugural lecture as Professor in 2007. ${ }^{16}$

As its legislative title suggested, the Employment Contracts Act was anti-collective in orientation, situating the individual contract between employer and employee/worker as the "dominant legal instrument" in regulating that relationship. ${ }^{17}$ Its replacement by the Employment Relations Act 2000 represented, on the other hand, something of a readjustment in regulation towards the greater protection of workers' interests, particularly through the introduction of a statutory requirement of "good faith" in the employment relationship. ${ }^{18}$

the Recession: Labour Force Changes and Labour Cost Reductions" [1992] Labour, Employment and Work in New Zealand 89; and Gordon Anderson and Cary Davis "Labour Flexibility and the Legal Requirement for Redundancy Dismissals" [1994] Labour, Employment and Work in New Zealand 299.

13 Inevitably this discussion gives rise to some repetition in references and so on which I hope the reader will excuse.

14 See for example Gordon Anderson "Procedural fairness and unjustified dismissal" (1983) 8 NZJIR 1; and Gordon Anderson "The origins and development of the personal grievance jurisdiction in New Zealand" (1988) 13 NZJIR 257.

15 Anderson, Brodie and Riley, above n 5.

16 Anderson "Employment Rights in an Era of Individualised Employment", above n 7.

17 Anderson Reconstructing New Zealand's Labour Law, above n 2, at 70.

18 This recalibration of the respective obligations in the employment relation through the "good faith"' concept was viewed positively, though with qualification, in Anderson "Employment Rights in an Era of Individualised Employment", above n 7, at 433-434. 
A considerable amount of Gordon's research output during the 1990s, and onwards, was given to these shifting regulatory approaches to the employment relation and their implications for work contracts in general. ${ }^{19}$ While the outcomes of this analysis are to a degree ambivalent, at the same time they lead to a singular overarching conclusion: statutory protections are the nub of labour law. ${ }^{20}$ These may be effective; they may also be targeted by courts and thus reduced in effectiveness. But what is clear, it seems, is that, in applying the common law, courts are generally more prone to adhere to the protection of property, and rights associated with property inherent in that law, than they are to be "innovative or progressive" in shaping it to fit the needs of employees and workers. ${ }^{21}$ Gordon's argument is that the increasing individualisation of employment relations, the decline of the influence of statutory protection and trade unions, and the consequent abiding influence of the common law underpinning of employment/work regulation of necessity leads him to question "the extent to which a nineteenth century construct rooted in serfdom is the appropriate legal model for employment in the 21st century". ${ }^{22}$ "The Twenty-First Century Employee", in Gordon's terms, requires an employment law that recognises: ${ }^{23}$

... that employees, as well as employers, take risks in an employment relationship and that the simplistic property-contract divide of the common law does not adequately regulate long term relationships where both parties make a significant investment.

19 See Gordon Anderson "The Employment Contracts Act 1991: an employers' charter?" (1991) 16 NZJIR 127; Gordon Anderson "Individualising the Employment Relationship in New Zealand: An Analysis of Legal Developments" in Stephen Deery and Richard Mitchell (eds) Employment Relations: Individualisation and Union Exclusion - An International Study (The Federation Press, Sydney, 1999) 204; Gordon Anderson "Good Faith in the Individual Employment Relationship in New Zealand" (2011) 32 Comp Lab L \& Pol'y J 685; Anderson Reconstructing New Zealand's Labour Law, above n 2, at chs 4-7; Gordon Anderson "The Common Law and the Reconstruction of Employment Relationships in New Zealand" (2016) 32 IJCLLIR 93; and Anderson, Brodie and Riley, above n 5.

20 "Legislation is an unequivocal signal of what a society values in the workplace relationship": Jane Bryson "Administering Workplace Relationships: From IR to HR" in Anderson and others (eds) Transforming Workplace Relations in New Zealand 1976-2016 (Victoria University Press, Wellington, 2017) 60 at 74.

21 Anderson "The Common Law and the Reconstruction of Employment Relations in New Zealand", above $n$ 19 , at 113. This strongly negative view of the common law contract of employment is also presented in some detail in Gordon Anderson "A Sea of Difference? A New Zealand Perspective on Australian Labour Law Reform" in Joellen Riley and Peter Sheldon (eds) Remaking Australian Industrial Relations (CCH, Sydney, 2008) 207.

22 See Gordon Anderson, Douglas Brodie and Joellen Riley "The Common Law and the Individual Employment Relationship: A Three Jurisdictional Perspective" (paper presented to the Fourth Labour Law Research Network Conference, Toronto, June 2017) at 17. See also Anderson "The Common Law and the Reconstruction of Employment Relationships in New Zealand", above n 19, at 113-116.

23 Gordon Anderson "Grasping the Moment: Some Cross-Tasman Thoughts on Australian Labour Law Reform" (2008) 18 ELRR 113 at 116-117. 


\section{LABOUR LAW EXPERIMENTS}

New Zealand may not hold as prominent a position in comparative scholarship on labour law as many other countries, but for one principal reason, at least, it does stand out as a notable case-study in labour law development. At two historical junctures, almost a century apart, New Zealand has been at what might be seen as the "forefront" of labour market regulation, utilising ideas and concepts not fully accepted or adopted elsewhere. The first of these "experiments" came with the introduction of the compulsory arbitration system in the form of the Industrial Conciliation and Arbitration Act $1894{ }^{24}$ The second came with the neo-liberal inspired lurch to the right in the shape of the aforementioned Employment Contracts Act. ${ }^{25}$ In this context, Gordon's extensive exploration of the evolution of New Zealand labour law serves as a record, not merely of legal change in a national jurisdiction, but as an analysis of how labour law "styles" respond to political and economic pressures: ${ }^{26}$

New Zealand's most fundamental changes to its labour law, those in 1894 and 1991, were the result of a

"perfect storm": an unusually fortuitous confluence of political, social and industrial factors.

While New Zealand was not the first country to consider the use of compulsory arbitration in dealing with industrial disputes, ${ }^{27}$ it was certainly the first country to adopt a complete model of the compulsory arbitration system and was the progenitor of the system as it evolved eventually throughout Australasia, ${ }^{28}$ featuring the collective regulation of employment conditions through state

24 See William Pember Reeves State Experiments in Australia and New Zealand (Grant Richards, London, 1902).

25 See Jane Kelsey The New Zealand Experiment: A World Model for Structural Adjustment? (Auckland University Press, Auckland, 1995).

26 Anderson Reconstructing New Zealand's Labour Law, above n 2, at 264. See generally Gordon Anderson "Competing Visions and the Transformation of New Zealand Labour Law" in Gordon Anderson and others (eds) Transforming Workplace Relations in New Zealand 1976-2016 (Victoria University Press, Wellington, 2017) 191; Gordon Anderson "Developments in the Legal Regulation of Collective Bargaining in New Zealand" (1990) 3 AJLL 227; Anderson "The Employment Contracts Act 1991: an employers' charter?", above n 19; Gordon Anderson "Collective Bargaining and the Law: New Zealand's Employment Contracts Act Five Years On" (1996) 9 AJLL 103; Gordon Anderson "Just a Jump to the Left? New Zealand's Employment Relations Act 2000" (2001) 14 AJLL 62; and Gordon Anderson "'The Sky Didn't Fall In': An Emerging Consensus on the Shape of New Zealand Labour Law?" (2010) 23 AJLL 94.

27 For example the Canadian province of Nova Scotia had tried versions of this in the 1880s: see Richard Mitchell "Solving the Great Social Problem of the Age: A Comparison of the Development of State Systems of Conciliation and Arbitration in Australia and New Zealand"' in Gregory S Kealey and Greg Patmore (eds) Canadian and Australian Labour History: Towards a Comparative Perspective (Australian Society for the Study of Labour History, NSW, 1990) 47.

28 And at the same time capturing considerable international attention for its experiment: see for example Henry Demarest Lloyd A Country Without Strikes: A Visit to the Compulsory Arbitration Court of New Zealand (Doubleday, New York, 1900). 
bodies and the incorporation of trade unions as agents in that system. ${ }^{29}$ Although the system was believed by some New Zealand observers to be inherently unstable, and from the 1970s onwards became subject to ongoing change (sometimes of a serious systemic nature), ${ }^{30}$ for the most part it was also considered to have "delivered a balance of working conditions and industrial stability that were acceptable to both capital and labour". 31 "The arbitral system", according to Gordon: ${ }^{32}$

...provided unions and workers with a degree of both relative and absolute protection of wages and working conditions. It did not challenge employer prerogative but did provide industrial stability, relatively low wages and standardised labour costs. Governments also enjoyed these benefits, but with the additional political benefits that the system required relatively little direct intervention, resulted in low levels of union militancy, and prevented serious industrial conflict.

As was the case with most labour lawyers, Gordon was less sanguine about the impact of the second major remodelling of New Zealand labour regulation in the shape of the Employment Contracts Act: a reform "strongly biased to one side of the employment relationship and ... which generated considerable emotion". ${ }^{33}$ As we noted earlier, this essentially deregulatory legislation embodied much of the neo-liberal platform which was, at that time, "characteristic of most AngloAmerican countries as well as other countries". ${ }^{34}$ What made the New Zealand case stand out was not so much the evident influential force of deregulatory ideas, but the extreme nature of the Act's approach which made New Zealand something of a leader in labour law reform: "deregulation in New Zealand was probably the most extensive, resulting in the most radical restructuring of labour law". ${ }^{35}$ This perception was confirmed in Gordon's comparative quantitative-measurement work on the evolution of New Zealand's labour law. ${ }^{36}$ It is a major narrative in Gordon's scholarship that the idea of labour law is connected with fundamental underlying principles of democracy and social justice. ${ }^{37}$ Consistent with that view, on the whole his responses to the fundamental tenets of the Employment

29 See Stuart Macintyre and Richard Mitchell (eds) Foundations of Arbitration: The Origins and Effects of State Compulsory Arbitration 1890-1914 (Oxford University Press, Melbourne, 1989) chs 4-5.

30 See Anderson "Competing Visions and the Transformation of New Zealand Labour Law", above n 26, at 196199.

31 At 195. A similar view of the benefits of the conciliation and arbitration system in its New Zealand form is expressed by Gordon in Anderson Reconstructing New Zealand's Labour Law, above n 2, at 21.

32 Anderson Reconstructing New Zealand's Labour Law, above n 2, at 21-22.

33 Gordon Anderson "The Richardson Years" (2002) 33 VUWLR 887 at 889.

34 Anderson Reconstructing New Zealand's Labour Law, above n 2, at 256.

35 At 256

36 See Gordon Anderson and others "The Evolution of Labor Law in New Zealand: A Comparative Study of New Zealand, Australia and Five Other Countries" (2011) 33 Comp Lab L \& Pol'y J 137.

37 We return to this issue later in this piece: see nn 61-66 and associated text. 
Contracts Act, and even to some of the legislation following that Act (including by Labour Governments), ${ }^{38}$ were generally critical in orientation.

\section{CROSS-TASMAN INTERACTIONS}

Cross-national commentary, observation and comparison have been a feature of interaction between New Zealand and Australian labour law and labour relations scholars since the earliest of times. ${ }^{39}$ This is hardly surprising given the similarities of the two countries in terms of global location, economic context, colonial heritage and so on. Of more direct relevance, however, has been the supposedly similar "legal structure" which has underpinned the labour relations systems of both countries for much of the 20th century, and the problems and tensions arising as these systems came increasingly under pressure for reform from the 1980s onwards. ${ }^{40}$ Among others, ${ }^{41}$ Gordon was a regular contributor to Australian books and journals detailing for the benefit of Australian labour lawyers the course of change in New Zealand labour law, and the responses of institutions and parties to that change. Between 1990 and 2010 he published five major articles (almost at regular five-yearly intervals) in the Australian Journal of Labour Law reporting on and analysing the flow of labour law reform in New Zealand, ${ }^{42}$ and to these must be added one or two other influential pieces. ${ }^{43}$

38 See for example Anderson "Competing Visions and the Transformation of New Zealand Labour Law", above n 26, at 203.

39 See for example Reeves, above n 24; and Dorothy McDaniel Sells "The Development of State Wage Regulation in Australia and New Zealand" (1924) 10 Int'l Lab Rev 607.

40 Anderson "A Sea of Difference? A New Zealand Perspective on Australian Labour Law Reform", above n 21 , at 207.

41 See for example the contributions of Margaret Wilson "Policy, Law and the Courts: An Analysis of Recent Employment Law Cases in New Zealand" (1995) 8 AJLL 203; "The New Industrial Law in New Zealand and its Impact on the Construction and Teaching of Industrial Law Courses " in Richard Mitchell (ed) Redefining Labour Law: New Perspectives on the Future of Teaching and Research (Centre for Employment and Labour Relations Law, University of Melbourne, Melbourne, 1995) 220; "Strike ballots: The New Zealand experience" (2016) 29 AJLL 194; and Richard Mitchell and Margaret Wilson "Legislative Change in Industrial Relations: Australia and New Zealand in the 1980s" in Mark Bray and Nigel Haworth (eds) Economic Restructuring \& Industrial Relations in Australia \& New Zealand: A Comparative Analysis (Australian Centre for Industrial Relations Research and Teaching, University of Sydney, Sydney, 2006) 38.

42 See Anderson "Developments in the Legal Regulation of Collective Bargaining in New Zealand", above n 26; Anderson "Collective Bargaining and the Law: New Zealand's Employment Contracts Act Five Years On", above n 26; Anderson "Just a Jump to the Left? New Zealand's Employment Relations Act 2000", above n 26; Gordon Anderson "Transplanting and Growing Good Faith in New Zealand Labour Law" (2006) 19 AJLL 1; and Anderson "'The Sky Didn't Fall In': An Emerging Consensus on the Shape of New Zealand Labour Law?", above n 26.

43 See Anderson "Individualising the Employment Relationship in New Zealand: An Analysis of Legal Developments", above n 19. 
Other work involving New Zealand and Australian scholars has been more directly comparative. ${ }^{44}$ Two issues which stand out are the similarities in labour law/industrial relations arrangements between New Zealand and Australia, and the differing, and diverging, responses in those systems to the aforementioned reform processes.

On the first issue, as we noted earlier, in terms of legislation, and the role of the state and trade unions, the fundamentals of the compulsory arbitration system were copied from New Zealand across to Australia in the very early 20th century, ${ }^{45}$ and remained relatively unaltered for close to 80 years. However, exactly how close the similarities in legal structure and operation of the two systems were tended more to be assumed than analysed. Recent Australian/New Zealand comparative work has revisited some of this ground, and challenged some of the earlier thinking. This work suggests, perhaps, that the differences in the two systems were more fundamental than appeared to be the case, and that such differences were found in important legal and institutional matters, as well as social, economic and political contexts within which the systems operated. ${ }^{46}$

Gordon's approach, on the other hand, tends to focus more on fundamental similarities than otherwise. In a valuable joint study with an Australian colleague Michael Quinlan, Gordon explored the role of the state in regulating work in Australia and New Zealand since colonisation. ${ }^{47}$ A notable aspect of this work was the highlighting by the authors of problems associated with comparative studies of the evolution of labour legislation and the methods employed in such studies. ${ }^{48}$ However, relevant to the present discussion, one section of the study was given over to the examination of the "shared ... critical features" 49 of the Australian and New Zealand industrial arbitration systems. Seven

44 See Mitchell and Wilson, above n 41; Mark Bray and Pat Walsh "Accord and Discord: The Differing Fates of Corporatism Under Labo(u)r Governments in Australia and New Zealand" (1995) 6(3) Labour \& Industry 1; Mark Bray and Pat Walsh "Differing Paths to Neo Liberalism? Comparing Australia and New Zealand" (1998) 37 Indus Rel 358; Michael Barry and Nick Wailes "Contrasting Systems? 100 Years of Arbitration in Australia and New Zealand" (2004) 46 JIR 430; Michael Barry and Nick Wailes "Revisiting the AustraliaNew Zealand Comparison" (2005) 30(3) NZJER 1; and Gordon Anderson and Michael Quinlan "The Changing Role of the State: Regulating Work in Australia and New Zealand 1788-2007" (2008) 95 Labour History 111. See also the very useful overview by Raymond Markey "Presidential Address: Historical Perspective and Trans-Tasman Currents in Industrial Relations" (2011) 21 Labour \& Industry 645.

45 The first relevant Australian legislation was in Western Australia (the Industrial Conciliation and Arbitration Act 1900 (WA)), followed by New South Wales (the Industrial Arbitration Act 1901 (NSW)), and the Australian Commonwealth (the Conciliation and Arbitration Act 1904 (Cth)).

46 See Richard Naughton The Shaping of Labour Law Legislation: Underlying Elements of Australia's Workplace Relations System (LexisNexis Butterworths, Chatswood (NSW), 2017) at ch 10. See also Barry and Wailes "Contrasting Systems? 100 Years of Arbitration in Australia and New Zealand", above n 44; and Barry and Wailes "Revisiting the Australia-New Zealand Comparison", above n 44.

47 Anderson and Quinlan, above n 44.

48 This is an important issue in its own right, and deserves greater attention, but we do not pursue it further here.

49 Anderson and Quinlan, above n 44, at 122. 
key aspects were identified by the authors; the use of tribunals; legal recognition of unions; virtual compulsory recognition of unions; encouragement of collective representation; awards of employment conditions covering the bulk of the workforce; the co-existence of collective bargaining; and an effective means of award enforcement. ${ }^{50}$ Taken together, the argument is that these common features establish the "arbitration era" (circa 1900-1970) across the two countries as being "essentially similar" in terms of their "legal structures". ${ }^{51}$ It goes without saying, of course, that much depends here on the various features that the various scholars select as part of their analysis, but at least at this level the outcome of Gordon's analysis would seem to be somewhat at odds with other recent characterisations of the two systems noted above. ${ }^{52}$

On the second issue, the radical and more or less instantaneous individualisation of the New Zealand labour law system through the Employment Contracts Act of 1991 may be contrasted with the slower, more piecemeal, approaches of various Australian governments from the early 1990s onwards, culminating in the Work Choices legislation of 2005. ${ }^{53}$ However, despite these differences in approach, in Gordon's view both cases present what might be regarded as a cautionary tale when it comes to labour law reform. The relative failure of these extreme measures indicates a failure by both New Zealand and Australian governments to pursue realistic reform agendas. "[O]pportunities for comprehensive labour law reform occur rarely, perhaps once in a generation". ${ }^{54}$ Even then: ${ }^{55}$

Opportunity alone is not enough. A reform agenda must be accompanied by a clearly articulated vision of the principles on which reform is to be based. In turn, that vision must be able to achieve a political consensus ...

which, as is well known, neither the New Zealand nor Australian reforms were able to secure in the long run. This returns us to an earlier-noted conviction inherent in Gordon's labour law scholarship: ${ }^{56}$

50 At $122-123$.

51 At 115

52 Again, this is an important issue in its own right but we do not pursue it further here.

53 See generally Julian Teicher, Rob Lambert and Anne O'Rourke (eds) WorkChoices: The New Industrial Relations Agenda (Pearson Education Australia, Sydney, 2006).

54 Anderson "A Sea of Difference? A New Zealand Perspective on Australian Labour Law Reform", above n 21 , at 220

55 Anderson "Grasping the Moment: Some Cross-Tasman Thoughts on Australian Labour Law Reform", above n 23, at 115

56 See above nn 37-39 and associated text. 
"fundamentally inequitable and iniquitous labour legislation is unacceptable in a modern democracy". ${ }^{57}$ Pragmatism in reform (at least in labour law reform) is preferable to ideology. ${ }^{58}$

\section{THE FUTURE?}

What we have noted so far in this brief summation of Gordon's contribution to labour law scholarship confirms his strong commitment to "social justice",59 and fairness between capital and labour. The central pillar in Gordon's conception of labour law is the role that it plays in protecting the access of working people (labour) to the material conditions necessary to life. ${ }^{60}$ In his discussion about labour law generally it is associated with "human rights", 61 "economic security", 62 "personal dignity", 63 even "survival". ${ }^{64}$ Perhaps it is the case that most labour lawyers come to the subject with a similar outlook, but it is a feature of Gordon's work that such underlying values are utilised regularly and unconditionally in his analysis.

The present period of (at least relative) consensus in New Zealand labour law seems, if at least temporarily, to have stabilised economic and industrial relations between labour and capital. ${ }^{65}$ The question remains, however, what the future might hold for labour law, and this appears as something of a pressing issue in Gordon's ruminations on the subject. ${ }^{66}$ Indeed, it is difficult to see any clear path for labour law development at an international and national level for many diverse reasons. As Jane Bryson has pointed out, "we are in a world of increasing social and economic inequality,

57 Anderson "A Sea of Difference? A New Zealand Perspective on Australian Labour Law Reform", above n 21 , at 220 .

58 See Gordon Anderson "Book Review: A New Province for Legalism: Legal Issues and the Deregulation of Industrial Relations" (1995) 37 JIR 312 at 314.

59 See Anderson Reconstructing New Zealand's Labour Law, above n 2, at 257.

60 See Anderson, Hughes and Duncan, above n 4, at 3.

61 See Gordon Anderson "Introduction" (2016) 41(3) NZJER 1.

62 See Anderson Reconstructing New Zealand's Labour Law, above n 2 at 15; and Anderson "Good Faith in the Individual Employment Relationship in New Zealand", above n 19, at 721.

63 Gordon Anderson "A Proposal for Four Key Reforms to New Zealand's Labour Law" (6 November 2017) Social Science Research Network <www.ssrn.com>.

64 See Anderson Reconstructing New Zealand's Labour Law, above n 2, at 258.

65 See Anderson "'The Sky Didn't Fall In': An Emerging Consensus on the Shape of New Zealand Labour Law?", above $n 26$

66 See for example Anderson Reconstructing New Zealand's Labour Law, above n 2, at 149, 258 and 260 ; Anderson "Competing Visions and the Transformation of New Zealand Labour Law", above n 26, at 206; and Anderson and others Mazengarb's Employment Law, above n 1, at [Intro 10]. See also Gordon Anderson "Transforming Workplace Relations: The Way Forward" (paper presented to "Transforming Workplace Relations - Learning from the Past and Looking to the Future, Victoria University of Wellington, Wellington, 28 February 2018). 
punctuated by the breakdown of alliances and communities, unstable democracies, environmental concerns, and unknown work futures". ${ }^{67}$ Such a context, of course, points to two things. First, it would seem unlikely that the conventional idea of labour law can possibly remain relevant as a general scheme for regulating labour, and what has occurred in labour and work organisation, and in industrial relations practices, in the past two decades or so, indicates that it has not. This is especially so if we consider the international situation generally where across many countries the so-called "dominant" labour law model ${ }^{68}$ has largely been ineffective, and in others is in retreat. Secondly, as Gordon has noted, the reformulation of a "normative" vision for what labour law might become is exceedingly problematical. ${ }^{69}$

Gordon's outlook here has been to point to the difficulties, but also to take a more measured approach to re-envisioning labour law. One recent contribution in this mode was made in the form of a discussion paper suggesting four major reforms to New Zealand's labour law. ${ }^{70}$ These reforms would include the establishment of a clear set of fundamental employment standards applicable to workers rather than just employees; the construction of stronger, more effective rights of employees to union representation and voice in the workplace; the establishment of a realistic collective bargaining system; and (as noted above) greater statutory recognition of the rights of workers to be treated with respect and dignity. These are, by no means, very radical proposals. Rather they are very much in keeping with his general pragmatic outlook. Labour law change should not diverge too dramatically from the past. Consensus requires moderate, fair, incremental adjustment.

Beyond these kinds of adjustments in labour law orthodoxy, however, Gordon's scholarly inquiry has at times addressed more expansive dimensions of the international labour law discussion. One example is his engagement with the debate on Amartya Sen's "Capability Concept", and its utilisation by Alain Supiot and his colleagues in a report prepared for the European Commission suggesting a way forward for the reform of labour law and social security in Europe. ${ }^{71}$ The Supiot Report was suggesting, in Gordon's view, nothing less than "a new approach to the governance of work" but from

67 Bryson, above n 20, at 73.

68 See Tzehainesh Teklè "Labour Law and Worker Protection in the South: An evolving tension between models and reality" in Labour Law and Worker Protection in Developing Countries (Hart Publishing, Oxford, 2010) 3 at 9 .

69 See Anderson Reconstructing New Zealand's Labour Law, above n 2, at 257. This question has occupied a considerable amount of academic attention since the late 1980s: see for example Guy Davidov and Brian Langille (eds) Boundaries and Frontiers of Labour Law (Hart Publishing, Oxford, 2006); Guy Davidov and Brian Langille (eds) The Idea of Labour Law (Oxford University Press, Oxford, 2011; and Ruth Dukes The Labour Constitution: The Enduring Idea of Labour Law (Oxford University Press, Oxford, 2014).

70 Anderson "A Proposal for Four Key Reforms to New Zealand's Labour Law", above n 63.

71 Amartya Sen Commodities and Capabilities (Oxford University Press, Delhi, 1985); and Alain Supiot Beyond Employment: Changes in Work and the Future of Labour Law in Europe (Oxford University Press, Oxford, 2001). 
his perspective the ideology of the common law system, where relevant (as in New Zealand), would be likely to act as a barrier to the types of reforms being suggested. ${ }^{72}$ While acknowledging that the ideas inherent in the capabilities approach were not entirely incompatible with New Zealand's labour law system, it remained the case that: ${ }^{73}$

To gain traction any radical change, such as a capability approach has to overcome the philosophical deadweight of the common law, a task that is likely to be extremely difficult where the common law is the only game in town unlike Europe.

A second instance concerns the global focus of debate in labour law generally. The relative lack of attention paid to labour law in the Asia-Pacific Region, along with Africa and South America for example, has generated a degree of criticism and response among scholars and institutions. ${ }^{74}$ None of this is news to those like Gordon who work in this region, a region which includes three of the four most populated countries on the planet, and which is characterised by many and varied systems of labour law, often drawn from, but also often strongly varying in practice from, a supposed orthodoxy largely typified in the earlier industrialised parts of the world.

Reviewing Bob Hepple's book Social and Labour Rights in a Global Context in 2003, Gordon noted that: ${ }^{75}$

Unfortunately the first thing that must be said about Social and Labour Rights is that it suffers from a somewhat limited concept of what constitutes "global". The collection of papers that make up the book are, with a couple of exceptions, largely confined to affairs of the member countries of the European Union. Indeed, apart from some limited references, the Southern hemisphere appears to have vanished entirely as have any countries that fall outside the membership of the OECD.

The reality is, of course, that a serious approach to labour law on a global basis requires a more detailed and interactive consideration of how labour is regulated, and what the impact of that regulation might be more widely and certainly needs to consider different types of regulation in countries of very different styles of socio/political economy. To some extent this is occurring in different ways. One of these is through publication. ${ }^{76}$ Another is through the establishment of more

72 See Gordon Anderson "The Capability Approach and the Legal Regulation of Employment: A Comment on Deakin" (2009) 34(1) NZJER 27 at 31.

73 At 32.

74 See for example Teklè, above n 68; and Sarah Mosoetsa and Michelle Williams (eds) Labour in the Global South: Challenges and Alternatives for Workers (International Labour Office, Geneva, 2012).

75 Gordon Anderson "Review Article: Labour Law in a Globalising World" (2003) 66 MLR 640 at 641.

76 See Teklè, above n 68; and Mosoetsa and Michelle, above n 74. See also Sangheon Lee and Francois Eyraud (eds) Globalization, Flexibilization and Working Conditions in Asia and the Pacific (Chandos Publishing, Oxford, 2008). 
inclusive institutional connections, one of which is the recently established Labour Law Research Network. Along with his other activities in the region, Gordon Anderson played an important supporting role in the establishment of that organisation.

The purpose of this brief overview of Gordon Anderson's career in New Zealand labour law has been to illustrate and affirm the significant role he has played in the development of the field over the past 40 years. As noted, this work has included institution building along with scholarly publication and policy work.

Speaking personally, I would like to congratulate him on his outstanding achievements, and I thank him for his collegiality and friendship over these many years. 
